\title{
Kako je Robinson oživio infinitezimal
}

\author{
Neda Lovričević, Anita Rezić
}

\section{Sažetak}

U radu je dan kratak povijesni pregled upotrebe infinitezimala u matematičkoj analizi, od njegovog početnog, intuitivno zasnovanog koncepta preko sugestivne Leibnizove misli i metode pa sve do Robinsonovog formalnog argumentiranja $\mathrm{u}$ korist infinitezimalne metode, ostvarenog sredstvima matematičke logike. Prikazana su svojstva hiperrealnih brojeva kojima se proširuje skup realnih brojeva, a sama upotreba infinitezimalne metode je detaljnije prikazana na primjerima iz diferencijalnog računa.

Ključni pojmovi: infinitezimal, hiperrealni brojevi, standardni dio hiperrealnog broja, zakon neprekidnosti, princip prijelaza, derivabilnost

\section{U čemu je „kvaka” s beskonačno malim veličinama}

Pojam infinitezimala ne treba dodatno pojašnjavati onima koji su iole ozbiljnije uključeni u matematiku. Tom beskonačno malenom broju, a ipak tvrdoglavo različitom od nule uvijek se vraćamo u procesu intuitivnog prihvaćanja novih spoznaja $u$ matematičkoj analizi. Priča o infinitezimalu postala je zanimljiva kad je upravo taj intuitivni koncept, na kojemu je matematička analiza i zasnovana, postao nedovoljan matematičarima 19. stoljeća. Oni su, u nastojanju da matematički izričaj učine koliko god je moguće preciznijim i strožim, u konačnici izagnali infinitezimal iz formalne matematičke analize. 
Ako pokušamo dati kratak povijesni presjek ove, ne baš tako kratke priče s puno obrata, onda se valja prisjetiti rane filozofske misli koja je bila začetak i one matematičke, o beskonačno malim veličinama u smislu materije, vremena i prostora. Tu spadaju npr. Zenonovi „argumenti protiv kretanja" s poznatim paradoksom o Ahileju i kornjači (5. st. pr. Kr.) ili Demokritov princip dijeljenja zaustavljen kod „nedjeljivih čestica - atoma" (4. st. pr. Kr.) U prvoj realiziranoj sistematizaciji logike u 4. st. pr. Kr. Aristotel je, zbog njihove nedorečenosti, izbjegavao uopće koristiti pojmove „beskonačno maleno” i „beskonačno veliko”. Ipak, još dugo nakon toga matematičari su ih uporno koristili.

Rasuđivanjem s dva različita aspekta pri dokazivanju naredne tvrdnje možda se najjednostavnije može ilustrirati zbunjujući moment nekadašnje upotrebe infinitezimala.

Tvrdnja 1. Površina kruga polumjera 1 jednaka je polovini njegova opsega.

Dokaz kardinala Nikole iz Kuesa (15. st.): Neka je krugu pripadajuća kružnica sastavljena od beskonačnog niza ravnih segmenata, međusobno jednakih i beskonačno malih. Tada je krug sastavljen od infinitezimalnih trokuta visine 1 . Kako je površina trokuta umnožak polovine osnovice i visine, to je onda zbroj površina trokuta jednak polovini zbroja njihovih osnovica. S druge strane, površina kruga jednaka je zbroju površina trokuta, a opseg kruga jednak je zbroju duljina osnovica trokuta. Time je površina kruga polumjera 1 jednaka polovini njegova opsega.

Oko same će se tvrdnje svi složiti. Ali, što bi to bio trokut s „,beskonačno malom osnovicom"? Čim je duljina osnovice veća od nule, njenim pribrajanjem beskonačan broj puta dobivamo beskonačno veliku sumu. Opseg kojeg očekujemo kao dobiveni zbroj je pak konačan! Dok smo u okruženju skupa realnih brojeva, Arhimedovo svojstvo realnih brojeva jamči da svaki realan broj različit od nule pribrojen sam sebi dovoljno mnogo puta može postati proizvoljno velik. U skladu s tim je Arhimed (3. st. pr. Kr.) i ustvrdio da ne postoje beskonačno mali brojevi! Drugim riječima, infinitezimali se po svojim svojstvima u tom kontekstu mogu smatrati nearhimedovskim brojevima, ma što god to značilo.

Arhimed je pak kod nekih slično formuliranih problema koristio "metodu ekshaustije" ili "metodu iscrpljivanja" kojom je izbjegavao korištenje pojma beskonačno malenih veličina. Taj postupak je blizak strogoj „,,$\delta$ " metodi zasnovanoj tek u 19. stoljeću. U tom se smislu ista tvrdnja o odnosu površine kruga polumjera 1 i njegovog poluopsega dokazuje sljedećim indirektnim dokazom „reductio ad absurdum”, i dalje promatrajući krug aproksimiran poligonom s beskonačno mnogo stranica. 


\begin{abstract}
„Arhimedovski" dokaz „reductio ad absurdum": Pretpostavimo suprotno od navedene tvrdnje, tj. da se površina kruga i polovina njegovog opsega razlikuju. Neka je $A$ pozitivan broj dobiven kao razlika veće i manje veličine od dviju navedenih. Oko kruga opišemo pravilni $n$-terokut, pri čemu je $n$ proizvoljan prirodni broj. Njegova površina je jednaka polovini njegovog opsega jer se sastoji od konačno mnogo trokuta visine 1 . Za dovoljno velik $n$ postižemo da se površina $n$-terokuta razlikuje od površine kruga za manje od $A / 2$. Istovremeno se opseg $n$-terokuta razlikuje od opsega kruga za manje od $A / 2$. Iz toga slijedi da se površina kruga i polovina opsega kruga razlikuju za manje od $A$, što je proturječno početnoj pretpostavci u dokazu. Stoga zaključujemo da $A$ mora biti nula, u skladu s onim što nam je i bio cilj dokazati.
\end{abstract}

Intuitivno prihvatljiv, ali logički manjkav, prvi dokaz Tvrdnje 1 mora pokleknuti pred drugim koji je logički zadovoljavajuć, iako pritom neizravan i „sitničav".

U nastavku članka (vidjeti Napomenu 7) dat ćemo i kompromisno razrješenje na istom primjeru tj. pristup kojega bi Abraham Robinson u 20. stoljeću primijenio pri analizi istog problema, a koji pomiruje suprotstavljene strane u priči o infinitezimalu, dajući prethodno odgovor na njegovo „biti ili ne biti” sudbinsko pitanje.

U međuvremenu su, tijekom 17. i 18. stoljeća, infinitezimali uspješno odolijevali pokušajima da ih se obezvrijedi. Veliki znanstvenici tog doba inspirirali su se njihovom primjenjivošću i točnim rezultatima koje su postizali u svojim izračunima uz pomoć infinitezimala, pritom se ne zabrinjavajući previše nedosljednostima u samoj metodi. Među poznatim imenima u znanosti tog doba istaknut ćemo Johannesa Keplera, Blaisea Pascala, Leonarda Eulera, Jakoba i Johanna Bernoullija te njihovog učenika markiza de L'Hospitala. Zajednički im je gotovo mistični zanos kojim promatraju beskonačno male veličine. Tako se, slično kao Nikola iz Kuesa prije njega, Kepler oslanjao na „božansko nadahnuće i instinkt kojemu ga podučava priroda". Pascal je na beskonačno malo i beskonačno veliko gledao kao na nešto ,što je priroda dala čovjeku ne da bi razumio, već da bi se divio," a L'Hospital je nekadašnja Aristotelova stroga pravila također zanemario govoreći u prilog infinitezimala: „Moglo bi se čak reći da se ova analiza proteže dalje od beskonačnosti jer se ne ograničava samo na beskonačno male razlike, već otkriva i odnose među razlikama tih razlika."

\title{
2 Robinson ostvaruje Leibnizovu želju
}

A onda su nastupili Gottfried Wilhelm Leibniz (1646. - 1716.) i Sir Isaac Newton (1642. - 1727.). Njihovo simultano, ali zasebno zasnivanje 
infinitezimalnog računa na poznatim problemima tangente i brzine bilo je tek na tragu nekadašnjeg mističnog zanosa pobornika infinitezimalne metode.

Problem tangente: Leibniz je definirao tangentu dane krivulje kao pravac koji prolazi njenim dvjema „beskonačno blizim” točkama. U tom smislu, ako promatramo kvadratnu parabolu kao graf funkcije $f(x)=x^{2}$ i odaberemo njene dvije beskonačno blize točke $(1,1)$ i $\left(1+\Delta x,(1+\Delta x)^{2}\right)$, gdje je $\Delta x$ broj manji od bilo kojeg realnog broja, a pritom veći od nule, onda je koeficijent smjera pravca koji prolazi danim dvjema točkama dan izrazom

$$
\frac{\Delta y}{\Delta x}=\frac{(1+\Delta x)^{2}-1}{1+\Delta x-1}=2+\Delta x .
$$

Na sličan način se dobiva i da je nagib pravca koji prolazi točkama $(1,1)$ i $\left(1-\Delta x,(1-\Delta x)^{2}\right)$ jednak $2-\Delta x$. Kako je nagib tangente $\mathrm{u}$ danoj točki krivulje realan broj, dok $2-\Delta x$ i $2+\Delta x$ to nisu, a pritom traženi koeficijent smjera mora biti po vrijednosti između $2-\Delta x$ i $2+\Delta x$, onda je jedino moguće rješenje za koeficijent smjera tangente broj 2 (Slika 1).

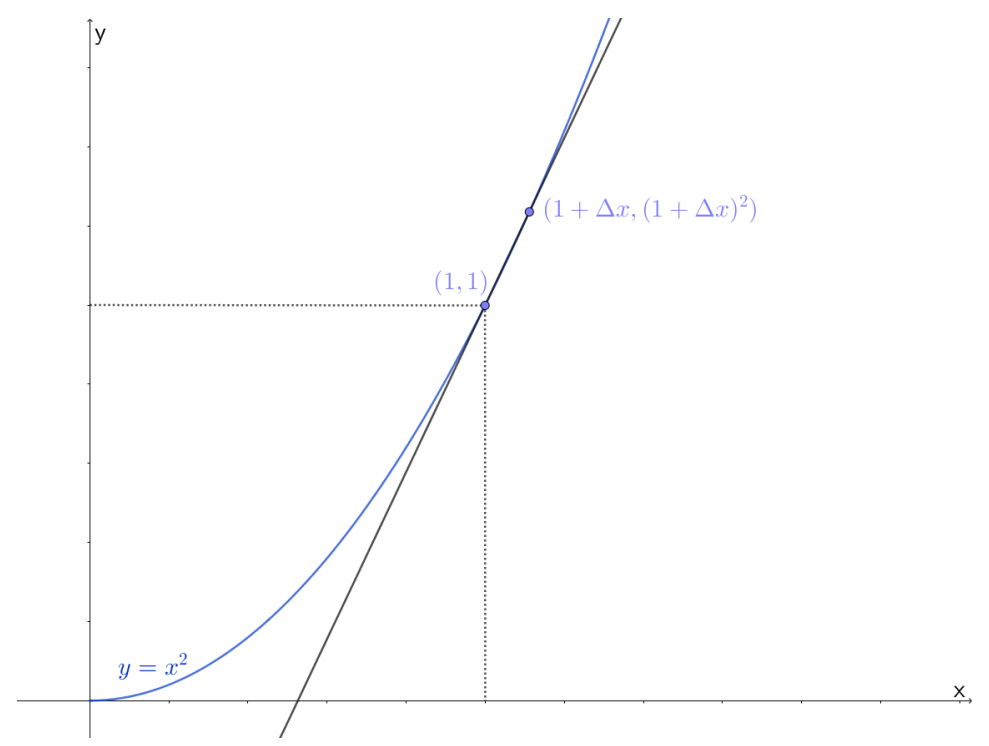

Slika 1

Leibnizova notacija $\frac{\Delta y}{\Delta x}$ ili $\frac{d y}{d x}$ i danas je u upotrebi, kako u standardnoj, tako i nestandardnoj analizi. 
Leibniz je, na tragu Nikole iz Kuesa i Johannesa Keplera, zasnovao poznati zakon neprekidnosti kojim ustanovljuje da se sva pravila koja vrijede pri računanju s realnim brojevima mogu prenijeti i na rad s beskonačno malim (ili velikim) vrijednostima. Tako je nastao Leibnizov koncept infinitezimalnog računa ili onoga što će se kasnije nazivati nestandardnom analizom. Leibnizov pristup infinitezimalima bio je najrazrađeniji do tada, ali, iako na pravom tragu, nije uspio precizirati svoje ideje. On je smatrao infinitezimale beskonačno malim brojevima različitima od nule koji su pritom manji od svakog pozitivnog realnog broja i veći od svakog negativnog realnog broja, ali ipak imaju ista svojstva kao i realni brojevi. Ova intuitivna predodžba o infinitezimalima koja je u praksi i izračunima donosila točne rezultate, ali pritom zanemarivala „dovoljno malene" veličine unutar izračuna, u sebi je sadržavala proturječnost, koje su i Leibniz i Newton bili svjesni. Pokušavali su im doskočiti posredno. Tako Leibniz nije tvrdio da infinitezimali zaista postoje, već da se može rasuđivati bez pogreške kao i da postoje. Newton je pak u svojim kasnijim radovima zaobilazio direktnu upotrebu infinitezimala služeći se fizikalno sugestivnim jezikom, posebno nakon oštre kritike svog najpoznatijeg djela „Principia”, iznesene od strane biskupa Berkeleya u djelu „The Analyst” iz 1734. godine. Berkeley vrlo ilustrativno i cinično sugerira da bi se infinitezimali koje Newton i Leibniz $\mathrm{u}$ smislu prirasta u krajnjim izračunima zanemaruju, trebali tada nazivati „duhovima pokojnih veličina”. Unatoč Berkeleyjevoj neoborivoj logici kojom cinično osporava upotrebu infinitezimala, ovi su „duhovi” iz nekog razloga opstali još cijelo stoljeće. Preciznije, sve do pojave poduzetnog „egzorcista” u 19. stoljeću koji ih je uspješno protjerao. Naime, u periodu kada se i sama matematika otcijepila od filozofije, fizike i tehničkih znanosti, otac moderne matematičke analize Karl Weierstrass (1815. - 1897.) ostvario je veliki povratak čistog matematičkog izraza u analizi, pri čemu se, naravno, ne umanjuje ni doprinos Cauchyja ili Bolzana. Definiranjem granične vrijednosti i uvođenjem poznatog para „ $\varepsilon, \delta$ " koji prati nadalje sve analitičke postupke, sve je postalo jasno i čisto unutar matematičke analize, a logička dosljednost je konačno bila zadovoljena. Ovi razlozi opravdali su i sve postojeće teško probavljive izraze s kojima se matematičari moraju boriti pri uvođenju pojmova ili dokazivanju tvrdnji. Na koncu, i sama „ $\varepsilon, \delta$ " konstrukcija s vremenom postaje jednako intuitivna za onoga tko se s njom često susreće, kao i sam intuitivni koncept problema tangente, brzine i, konačno, „zanemarivanja beskonačno malenih veličina." U ovoj zaokruženoj priči koja je bacila novo svjetlo na matematičku analizu ipak je ostala jedna sjena: dug prema infinitezimalu.

Leibnizova želja: „Raspolažem s tako mnogo ideja za koje bih želio da jednog dana budu od koristi nekome tko će im moći pris- 
tupiti analitičnije i dublje negoli sam to ja u mogućnosti te tako genijalnost svoga uma pridružiti mom djelu."

Zaista, želja mu se ispunila. Abraham Robinson (1918. - 1974.) bio je vrlo inspiriran Leibnizovim radom na infinitezimalima te je često znao reći da bi volio „ući u Leibnizovu glavu” u potrazi za načinom da njegove ideje prevede u prihvatljiv oblik za matematičare današnjice. Kao zaljubljenik u povijest i filozofiju matematike, a u prvom redu logičar, Robinson je postigao taj cilj upravo koristeći alate matematičke logike. U Robinsonovoj knjizi „Nestandardna analiza” objavljenoj 1966. godine izneseni su rezultati njegovog istraživanja. Nakon što je E. Hewitt 1948. godine u svom radu upotrijebio naziv „hiperrealni brojevi” za proširenje skupa realnih brojeva, tj. skup koji osim samih realnih brojeva sadrži i beskonačno velike i beskonačno malene brojeve (infinitezimale), Robinson je 1961. godine naslutio da se strogi pristup infinitezimalima u matematičkoj analizi zasnovan na davnoj Leibnizovoj ideji može uspostaviti upravo korištenjem sustava hiperrealnih brojeva, kao i alata matematičke logike. Shvatio je da se kontradiktorno svojstvo infinitezimala da su kao pozitivni brojevi manji od svakog pozitivnog realnog broja može razriješiti konstrukcijom sistema koji sadrži infinitezimale, a koji je identičan sistemu realnih brojeva obzirom na sva svojstva koja se mogu izraziti nekim formalnim logičkim jezikom. Pritom će se navedena proturječnost, uvidio je, izbjeći na način da se opisano svojstvo infinitezimala neće moći izraziti u tom formalnom jeziku.

Ako taj formalni jezik kojim govorimo o standardnom ambijentu $M$ skupa realnih brojeva $\mathbb{R}$ označimo s $\mathcal{L}$, onda je svaka rečenica u $\mathcal{L}$ propozicija o strukturi $M$ i kao takva mora biti istinita ili lažna. Ako je $\mathcal{K}$ skup svih pripadnih istinitih rečenica, onda je matematička struktura $M$ model za $\mathcal{K}$. Dakle, svaka rečenica u $\mathcal{K}$, interpretirana tako da se odnosi na $M$, je istinita. Ono što je pritom bitno jest da uz standardni model $M$ postoje i drugi, nestandardni modeli za $\mathcal{K}, \mathrm{u}$ istom jeziku $\mathcal{L}$. Iako bitno različite od $M$, za te nestandardne matematičke strukture koje ćemo označiti s $M^{*}$, također vrijedi da je svaka rečenica u $\mathcal{K}$ istinita, iako uslijed reinterpretiranih simbola jezika $\mathcal{L}$, ima različito značenje od ranijeg. Naredni shematski prikaz (Slika 2) prema 11 pokazuje ulogu formalnog jezika kao posrednika među navedenim strukturama. Norveški logičar T. A. Skolem prvi je otkrio postojanje nestandardnih modela na primjeru izučavanja strukture skupa $\mathbb{N}$ prirodnih brojeva. Robinsonu je to poslužilo kao motivacija da na sličan način promotri i skup realnih brojeva i standardne relacije diferencijalnog i integralnog računa koje bi mogao obogatiti infinitezimalnom metodom, ovaj put logički zasnovanom. Pritom se koristio teoremom kompaktnosti koji je posljedica poznatog Gödelovog teorema potpunosti, a koji tvrdi da ako za svaki konačan podskup skupa rečenica jezika $\mathcal{L}$ teorije 1 . reda postoji struk- 


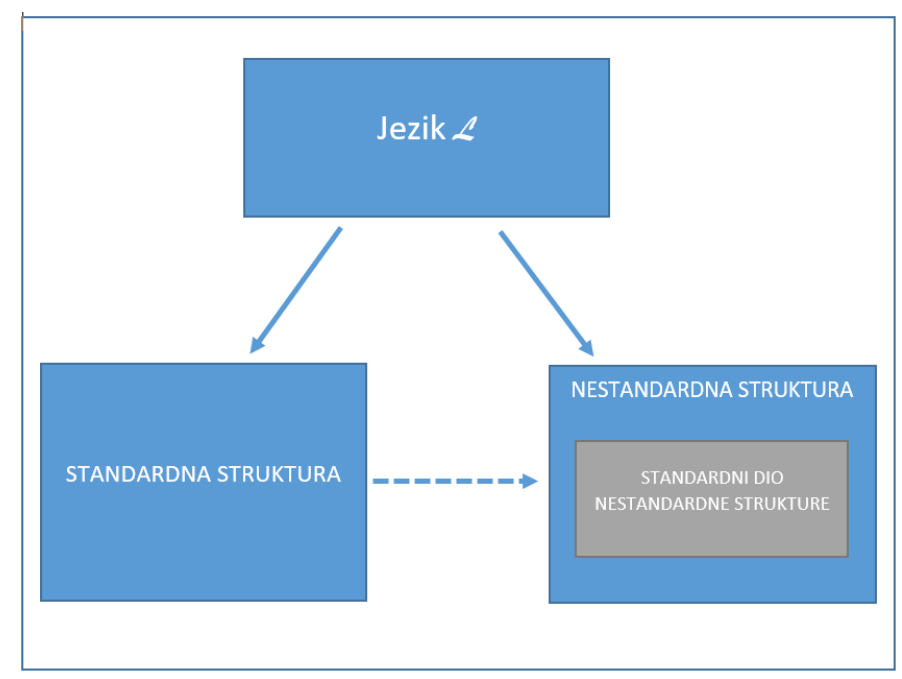

Slika 2

tura 1. reda koja taj podskup čini istinitim, onda postoji struktura 1. reda koja čini sve rečenice tog skupa istinitima. Sljedeći primjer daje naslutiti kako postojanje infinitezimala slijedi iz teorema kompaktnosti.

Primjer 1. Promotrimo beskonačnu familiju rečenica:

„r je broj veći od nule i manji od 1." "r je broj veći od nule i manji od $\frac{1}{2}$." "r je broj veći od nule i manji od $\frac{1}{3}$." "r je broj veći od nule i manji od $\frac{1}{4}$."

Obzirom na standardnu strukturu skupa $\mathbb{R}$, svaki konačan podskup rečenica je istinit jer za $n \in \mathbb{N}$ možemo primjerice za $r$ izabrati $\frac{1}{2 n}$. Međutim, ukoliko promotrimo cijeli beskonačni skup ovakvih rečenica, on je lažan za istu promatranu matematičku strukturu. Koliko god malen $r$ izabrali, uvijek će postojati $n \in \mathbb{N}$ takav da je $\frac{1}{n}<r$.

Prema teoremu kompaktnosti, postoji (nestandardna) struktura $\mathrm{u}$ kojoj su sve rečenice beskonačne familije prethodnog primjera istinite. Takva nestandardna struktura sadrži dakle i pozitivan broj $r$ koji je manji od svakog broja $\frac{1}{n}$, gdje je $n \in \mathbb{N}$. Drugim riječima, $r$ je infinitezimal.

I dok je svaka tvrdnja koja se može iskazati u formalnom jeziku $\mathcal{L}$ za standardne realne brojeve istinita i za infinitezimale, uz odgova- 
rajuću interpretaciju, za infinitezimale ipak ne moraju vrijediti svojstva zajednička svim standardnim realnim brojevima, ukoliko se ta svojstva ne mogu izraziti formalnim jezikom $\mathcal{L}$. Sljedeći primjer to potkrepljuje.

Primjer 2. Prisjetimo se da Arhimedovo svojstvo skupa $\mathbb{R}$ (ili Arhimedov aksiom) kaže da za svaki realan broj $r$ postoji $n \in \mathbb{N}$ tako da $r$ pribrojen sam sebi $n$ puta može „premašiti” bilo koji drugi realan broj. Promotrimo beskonačnu familiju rečenica kojom se opisuje Arhimedovo svojstvo skupa $\mathbb{R}$ :

$$
\begin{gathered}
r>1 . \\
r+r>1 . \\
r+r+r>1 . \\
r+r+r+r>1 .
\end{gathered}
$$

Primijetimo da su za svaki pozitivan realan broj $r$ istinite sve, osim konačno mnogo rečenica navedene beskonačne familije. Isto tako, prisjetimo se da je upravo opisano Arhimedovo svojstvo ono prema kojemu infinitezimali ne mogu postojati. Zaista, ukoliko je $r$ infinitezimalan broj (mogli bismo ga u ovom kontekstu nazvati i pseudorealnim), nijedna konačna suma od $r$ ne može biti veća od 1 .

Davni zaključak o nepostojanju infinitezimala argumentacijom kao u prethodnom primjeru mijenja se u svjetlu novih spoznaja i glasi: Činjenica da je Arhimedovo svojstvo istinito u standardnoj strukturi, a neistinito u nestandardnoj tek pokazuje da se to svojstvo ne može izraziti rečenicom jezika $\mathcal{L}$. Dakle, infinitezimali se ponašaju različito od standardnih objekata u onim svojstvima koje sam jezik $\mathcal{L}$ ne formalizira, dok se u ostalim, formaliziranima, ponašaju poput njih.

$\mathrm{Na}$ samu nestandardnu strukturu skupa realnih brojeva koja sadrži infinitezimale i beskonačne veličine može se gledati kao na svojevrsno proširenje njegove standardne strukture, iako postoje konceptualne razlike. Zahvaljujući Robinsonovoj nestandardnoj analizi, infinitezimali po prvi put $\mathrm{u}$ povijesti $\mathrm{u}$ matematičku analizu ne moraju ulaziti koristeći se skrovitim prilaznim putevima.

Potrebno je naglasiti da je ovdje opisan logički koncept Robinsonove metode vrlo sažet jer nam struktura članka ne dopušta njenu detaljniju razradu. Detaljniji i precizniji tretman može se naći primjerice u [2] i [3], a potrebna podloga iz područja matematičke logike u [5]. 


\section{O intuitivnom i o preciznom definiranju hiperrealnih brojeva}

Vrlo sugestivnu predodžbu, intuitivnu za početak, o skupu hiperrealnih brojeva $\mathbb{R}^{*}$ dao je H. J. Keisler u [3]. Hiperrealni brojevni pravac ilustrativno je predočio koristeći se zamišljenim postupkom promatranja neizmjerno malenih okolina brojeva ,infinitezimalnim mikroskopom” te dohvaćajući beskonačno daleke dijelove pravca „beskonačnim teleskopom", kao na Slici 3 .

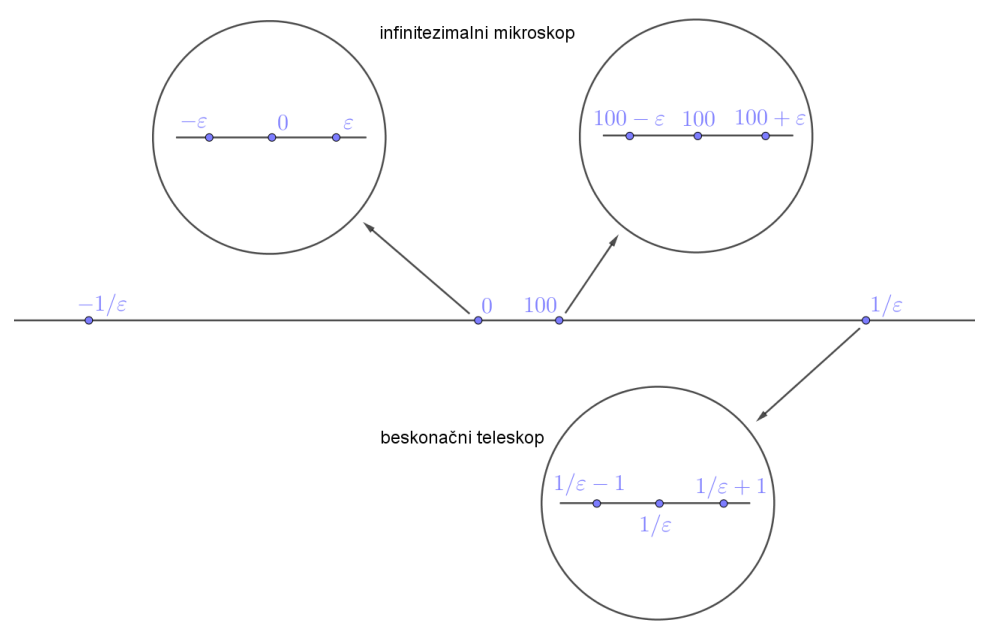

Slika 3

Model prikaza skupa brojeva na brojevnom pravcu naslijeđen je od skupa realnih brojeva te je tako realni brojevni pravac podskup hiperrealnog, $\mathrm{s}$ tim da svaki realan broj $r$ posjeduje okolinu hiperrealnih brojeva koji su mu „beskonačno blizu”. Posebno, hiperrealni brojevi beskonačno blizu nuli nazivaju se infinitezimalima. Realni brojevi sa svojim opisanim hiperrealnim okolinama promotrenima „mikroskopom” spadaju u konačni dio hiperrealnog pravca.

Definicija 1. Hiperrealan broj naziva se infinitezimalom ukoliko je različit od nule, manji od svakog pozitivnog $i$ veći od svakog negativnog realnog broja.

Brojevi recipročni infinitezimalima su beskonačni hiperrealni brojevi, dohvaćeni „teleskopom”. 
Definicija 2. Hiperrealan broj naziva se beskonačnim ukoliko je veći od svakog pozitivnog ili manji od svakog negativnog realnog broja. Ukoliko hiperrealan broj nije beskonačan, kažemo da je konačan.

Kako je Robinson nazivao realne brojeve „standardnima”, a ostale hiperrealne brojeve „nestandardnima”, tako se i njegov novi pristup matematičkoj analizi naziva nestandardnim ili naprosto govorimo o nestandardnoj analizi. Ona je, zahvaljujući Robinsonu, ovaj put rigorozno zasnovana na tri osnovna principa: princip proširenja, princip prijenosa (transfera) i princip standardnog dijela.

Pri konstruiranju bilo kojeg brojevnog sustava može se birati aksiomatski pristup (navođenjem aksioma za dani sustav) ili induktivni pristup (koji kreće od skupa prirodnih brojeva i dalje nadograđuje redom ostale sustave). Induktivni pristup izgradnji skupa hiperrealnih brojeva iz realnih koristi metodu ultrafiltera, sličnu onoj kojom se iz već izgrađenog skupa racionalnih brojeva izgrađuje skup realnih brojeva (vidjeti primjerice u 3]). Ovdje ćemo se ipak zadržati na aksiomatskom pristupu.

Uz poznate aksiome za skup realnih brojeva (aksiomi računanja, aksiomi uređaja i aksiom potpunosti), navodimo i aksiome skupa hiperrealnih brojeva koji se temelje na već spomenutim principima proširenja i prijenosa.

\section{Aksiom proširenja}

(1) Skup realnih brojeva $\mathbb{R}$ je podskup skupa hiperrealnih brojeva $\mathbb{R}^{*}$.

(2) Postoji relacija $<^{*}$ na $\mathbb{R}^{*}$, takva da je relacija standardnog uređaja $<$ na $\mathbb{R}$ podskup relacije $<^{*}$.

(3) Postoji hiperrealni broj $\varepsilon$, takav da je $0<^{*} \varepsilon i \varepsilon<^{*} r$, za svaki pozitivan realan broj $r$.

(4) Za svaku realnu funkciju $f$ jedne ili više varijabli postoji hiperrealna funkcija $f^{*}$ istog broja varijabli koja se naziva prirodnim proširenjem funkcije $f$.

Drugim riječima, realni brojevni pravac je podskup hiperrealnog brojevnog pravca, postoji barem jedan pozitivni infinitezimal (ujedno možemo reći da postoji barem jedan broj koji je hiperrealan, a da pritom nije realan) te postoji proširenje realnih funkcija realnih varijabli hiperrealnim funkcijama hiperrealnih varijabli, za koje ćemo narednim aksiomom osigurati da imaju ista svojstva kao i početne (realne) funkcije. 


\section{Aksiom prijenosa (transfera)}

Svaki (standardni) iskaz koji je istinit za realne brojeve također je istinit $i$ za hiperrealne brojeve.

Ovaj aksiom nadograđuje davni, intuitivno zasnovani Leibnizov zakon neprekidnosti dajući mu konačnu matematičku implementaciju.

Aksiomom prijenosa prevode se svi aksiomi računanja i uređaja skupa realnih brojeva, kao standardni realni iskazi, na skup hiperrealnih brojeva. To jedino nije slučaj za aksiom potpunosti skupa realnih brojeva: Skup svih infinitezimala ili svih konačnih hiperrealnih brojeva ne može podlijegati istom opisu intervala kao realni brojevi.

Treći princip na kojem je izgrađen skup hiperrealnih brojeva je princip standardnog dijela hiperrealnog broja. U nastavku je formuliran kao teorem kojemu zbog važnosti u pristupu navodimo i dokaz, no prije toga potrebno nam je precizirano značenje nekih pojmova.

Definicija 3. Za dva hiperrealna broja a i b kažemo da su međusobno beskonačno blizu $i$ pišemo $a \approx b$ ukoliko je njihova razlika $a-b$ infinitezimal ili nula.

U smislu prethodne definicije, za proizvoljan infinitezimal $\delta$ možemo pisati $\delta \approx 0$. Isto tako, ukoliko su $a$ i $b$ realni brojevi, oznaka $a \approx b$ ukazuje na to da je njihova razlika realna te je, dakle, jednaka nuli. Drugim riječima, tada je $a=b$.

Leibnizova „monadologija”: Koristeći se terminima Leibnizove ontološke misli Robinson je beskonačno blize brojeve smatrao pripadnima istoj „monadi”, dok je primjerice za sve one čija je razlika konačan broj govorio da su u istoj „galaktici”. Tako su svi realni brojevi u istoj galaktici koju je nazivao glavnom galaktikom, te u njoj svaka monada sadrži jedan i samo jedan realni broj. Drugim riječima, ta je monada upravo infinitezimalna okolina danog realnog broja.

Definicija 4. Neka je a konačan hiperrealan broj. Standardni dio broja a, u oznaci st(a) je realan broj koji je beskonačno blizu a.

Primijetimo da za beskonačne hiperrealne brojeve standardni dio nije definiran.

U narednom teoremu dokazuje se postojanje i jedinstvenost standardnog dijela konačnog hiperrealnog broja.

Teorem 5 (Teorem o standardnom dijelu). Za svaki konačan hiperrealan broj a postoji jedinstveni realni broj $r$ koji je beskonačno blizu broju $a$. 
Dokaz. Neka je $A$ skup svih realnih brojeva manjih od $a$. Kako je svaki realan broj između bilo koja dva elementa u $A$ i sam element od $A$, skup $A$ je interval. Hiperrealni broj $a$ je konačan te $A$ mora biti oblika $\langle-\infty, r\rangle$ ili $\langle-\infty, r]$, gdje je $r$ realan broj. Svaki realan broj $s$ koji je strogo manji od $r$ pripada $A$ te je stoga $s<a$. S druge strane, svaki realan broj $t$ strogo veći od $r$ ne pripada $A$ te je $t \geq a$. Slijedi da zaista postoji realan broj $r$ beskonačno blizu broju $a$.

Jedinstvenost dokazujemo pretpostavljajući suprotno, tj. da postoje dva realna broja $r$ i $s$, takva da je $r \approx a$ i $s \approx a$. Tada je i $r \approx s$. Kako se radi o realnim brojevima $r$ i $s$, vrijedi da je $r=s$.

U iduća dva primjera promatramo dvije hiperrealne funkcije, i to jednu koja jest prirodno proširenje realne funkcije realne varijable, i jedne koja to nije, a vezana je za upravo definirani standardni dio hiperrealnog broja.

Primjer 3. Promotrimo funkciju identiteta $f: \mathbb{R} \rightarrow \mathbb{R}, f(x)=x$. Primjenom aksioma prijenosa je $f(x)=x$ istinito i za sve hiperrealne brojeve $x$ te je definirano prirodno proširenje $f^{*}$ dane funkcije $f$. Time je $f^{*}(x)=x$, za sve hiperrealne brojeve $x$. Graf ove hiperrealne funkcije prikazan je na Slici 4 Keislerovim „infinitezimalnim mikroskopom”, prema [3].

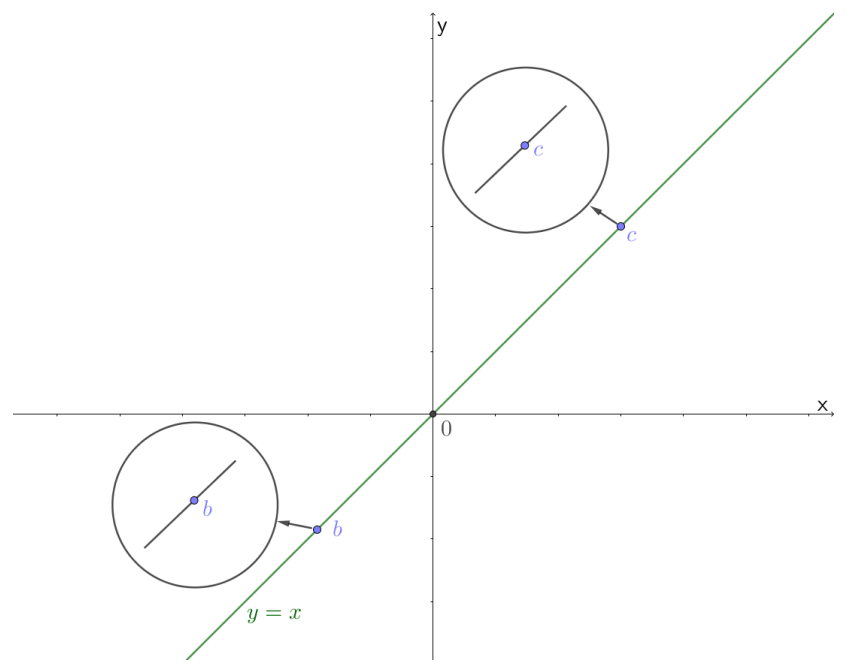

Slika 4

Primjer 4. Kada govorimo o funkciji standardnog dijela broja koja je definirana izrazom $s t(x)=x$, onda treba uočiti razliku u odnosu na već 
promatranu funkciju identitete $f$ iz Primjera 3 Dok funkcija identitete $f$ svoje proširenje $f^{*}$ gradi na domeni $\mathbb{R}^{*}$, funkcija standardnog dijela može uzeti za domenu svog proširenja samo konačne medu hiperrealnim brojevima. Znači, za beskonačne $x$ proširena funkcija standardnog dijela nije definirana. S druge strane, za konačne $x$ koji nisu realni brojevi vrijedi da je $s t(x) \neq x$. Promatrani ,infinitezimalnim mikroskopom”, infinitezimalni dijelovi grafa hiperrealne funkcije standardnog dijela hiperrealnog broja su horizontalni pravci, za razliku od grafa funkcije identitete (usporediti slike 4 i 5). Dakle, funkcija standardnog dijela nije prirodno proširenje funkcije identiteta.

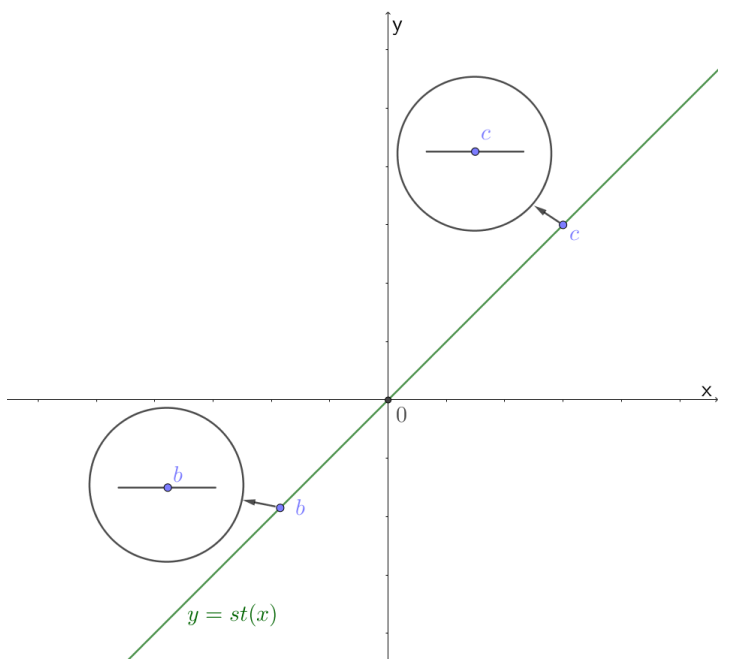

Slika 5

Idući teorem daje osnovna svojstva računanja sa standardnim dijelovima brojeva.

Teorem 6. Neka su a i b konačni hiperrealni brojevi. Tada vrijedi:

(1) $s t(-a)=-s t(a)$.

(2) $\operatorname{st}(a+b)=\operatorname{st}(a)+\operatorname{st}(b)$.

(3) $s t(a-b)=s t(a)-s t(b)$.

(4) $\operatorname{st}(a b)=\operatorname{st}(a) \operatorname{st}(b)$.

(5) Ako je st $(b) \neq 0$, onda je st $(a / b)=\operatorname{st}(a) /$ st $(b)$. 
(6) $\operatorname{st}\left(a^{n}\right)=(s t(a))^{n}$.

(7) Ako je $a \geq 0$, onda je st $(\sqrt[n]{a})=\sqrt[n]{\operatorname{st}(a)}$.

(8) Ako je $a \leq b$, onda je st $(a) \leq s t(b)$.

Dokaz. Dokazat ćemo tvrdnje (4) i 8).

Neka je $r$ standardni dio hiperrealnog broja $a$, a $s$ standardni dio hiperrealnog broja $b$. Tada ih možemo zapisati u obliku:

$$
a=r+\delta \quad \text { i } \quad b=s+\varepsilon,
$$

pri čemu su $\delta$ i $\varepsilon$ infinitezimali. Dokazujemo tvrdnju (4):

$$
\begin{aligned}
a b & =(r+\delta)(s+\varepsilon) \\
& =r s+r \varepsilon+\delta s+\delta \varepsilon \approx r s .
\end{aligned}
$$

Prema definiciji je tada $s t(a b)=r s=s t(a) s t(b)$.

Dokažimo sada i tvrdnju (8). Iz pretpostavke $a \leq b$ slijedi da je $s t(a)-$ $s t(b) \leq \varepsilon-\delta$. Kako se na lijevoj strani radi o realnom broju, a na desnoj o infinitezimalu, to mora vrijediti da je $s t(a)-s t(b) \leq 0$ pa je zaista $s t(a) \leq s t(b)$.

Primjer 5. Izračunajmo standardni dio složenijeg hiperrealnog izraza:

$$
3 x^{2}+3 x \Delta x+(\Delta x)^{2},
$$

gdje je $x \in \mathbb{R}$, a $\Delta x$ infinitezimal.

Koristeći se tvrdnjama Teorema 6 možemo pisati:

$$
\begin{aligned}
s t\left(3 x^{2}+3 x \Delta x+(\Delta x)^{2}\right) & =s t\left(3 x^{2}\right)+s t(3 x \Delta x)+s t\left((\Delta x)^{2}\right) \\
& =3 x^{2}+s t(3 x) \operatorname{st}(\Delta x)+s t\left((\Delta x)^{2}\right) \\
& =3 x^{2}+3 x \cdot 0+0^{2}=3 x^{2} .
\end{aligned}
$$

Napomena 7. Konačno, prisjetimo se ovdje $i$ Tvrdnje 1 čiji je jedan „dokaz" najprije prikazan infinitezimalnom metodom Nikole iz Kuesa, a drugi je arhimedovski, reductio ad absurdum, srodan klasičnoj „,,$\delta$ ” metodi. Robinsonovo razrješenje podupire argumentaciju Nikole iz Kuesa, pridodajući joj strožu matematičku podlogu. U njegovom je nestandardnom pristupu, naime, površina kruga promatranog već opisanim načinom Nikole iz Kuesa, standardni dio sume beskonačno mnogo infinitezimala. 


\section{Neke primjene u diferencijalnom računu}

Zanimljivo je promotriti kako se neki od temeljnih pojmova diferencijalnog računa uvode na nestandardan način, upotrebom infinitezimala. Nekoliko primjera poslužit će ilustriranju osnovnih principa korištenja infinitezimalne metode pri dokazivanju tvrdnji. Krenimo s nestandardnom definicijom pojma neprekidne funkcije.

Definicija 8. Za funkciju $f: I \rightarrow \mathbb{R}, I \subseteq \mathbb{R}$ kažemo da je neprekidna $\boldsymbol{u}$ točki $c \in I$ ukoliko za svaki hiperrealni broj $p \approx c$ vrijedi da je $f(p) \approx$ $f(c)$. Funkcija je neprekidna na I ukoliko je neprekidna u svakoj točki iz $I$.

Promatrat ćemo realne funkcije realne varijable koje imaju svoja prirodna proširenja na skupu hiperrealnih brojeva.

Primjer 6. Pokažimo da je funkcija definirana s $f(x)=4 x^{2}-2 x+1$ neprekidna u točki $x=3$.

Promotrimo hiperrealan broj $p \approx 3$. Vrijedi da je $p=3+\delta$, gdje je $\delta$ infinitezimal ili 0 . Tada je

$$
f(p)=4 \delta^{2}+22 \delta+31 \approx 31=f(3) .
$$

Primjer 7. Pokažimo da je funkcija definirana s $f(x)=x \sin x+2$ neprekidna u točki $x=-1$.

Promotrimo hiperrelan broj $p \approx-1$. Vrijedi da je $p=-1+\delta$, gdje je $\delta$ infinitezimal ili 0. Tada je

$$
\begin{aligned}
f(p)= & -\sin (-1) \cos \delta-\cos (-1) \sin \delta \\
& +\delta \sin (-1) \cos \delta+\delta \cos (-1) \sin \delta+2 \\
\approx & -\sin (-1)+2=f(-1) .
\end{aligned}
$$

Definirat ćemo na nestandardan način i derivabilnost funkcije te tako precizirati Lebinizov pristup problemu tangente.

Zbog preglednijeg zapisa formula, umjesto dosadašnje oznake st $(x)$, $\mathrm{u}$ daljnjem ćemo tekstu standardni dio hiperrealnog broja $x$ označavati $\mathrm{s} x$.

Definicija 9. Neka je $I \subseteq \mathbb{R}$ te $c \in I$. Ako je za funkciju $f: I \rightarrow \mathbb{R}$ izraz

$$
\frac{f(c+\Delta x)-f(c)}{\Delta x}
$$

konačan broj $i$ ima isti standardni dio za svaki infinitezimal $\Delta x$, onda kažemo da je funkcija $f$ derivabilna u točki c te je derivacija funkcije $f$ u točki c definirana $s$

$$
f^{\prime}(c)=\frac{f(c+\Delta x)-f(c)}{\Delta x}=\frac{\Delta f}{\Delta x} .
$$


Ako je $f$ derivabilna u svakoj točki otvorenog intervala, onda je na tom intervalu definirana nova funkcija $f^{\prime}$ koju nazivamo derivacijom funkcije $f$.

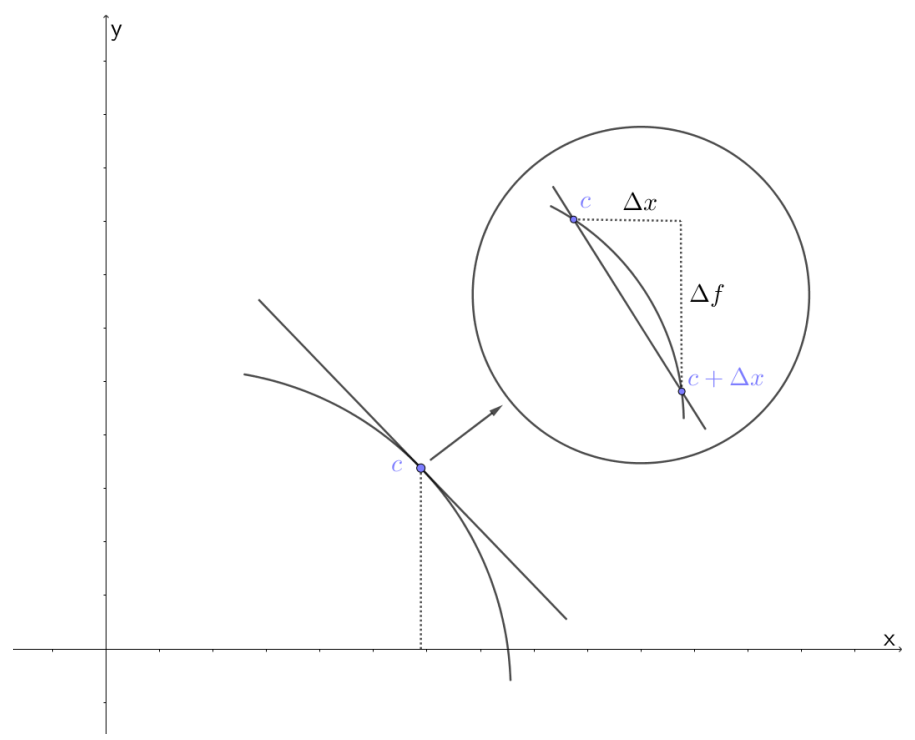

Slika 6

Teorem 10. Ako je $f$ derivabilna u točki $c$, onda je $f$ i neprekidna $u$ točki c.

Dokaz. Za dani infinitezimal $\Delta x$ je $\frac{f(c+\Delta x)-f(c)}{\Delta x}$ konačan broj prema definiciji derivabilnosti, što je moguće samo ukoliko je $f(c+\Delta x)-f(c)$ infinitezimal ili 0 , a što prema definiciji daje neprekidnost funkcije $u$ $c$.

Iz definicije slijedi da je derivacija linearne funkcije $f(x)=m x+n \mathrm{u}$ točki $c$ jednaka upravo koeficijentu smjera, tj. nagibu pripadnog grafapravca:

$$
f^{\prime}(c)=\frac{f(c+\Delta x)-f(c)}{\Delta x}=\frac{m c+m \Delta x+n-m c-n}{\Delta x}=m,
$$

za sve $\Delta x$. 
Primjer 8. Pokažimo da je funkcija definirana s $f(x)=x^{3}$ derivabilna $\mathrm{u}$ točki $x_{0}=1$ i odredimo njenu derivaciju u toj točki.

$$
\frac{\Delta f}{\Delta x}=\frac{(1+\Delta x)^{3}-1}{\Delta x}=3+3 \Delta x+(\Delta x)^{2} .
$$

Kako je $\Delta x$ infinitezimal, izraz $3 \Delta x+(\Delta x)^{2}$ je također infinitezimalan te je hiperrealni broj $3+3 \Delta x+(\Delta x)^{2}$ beskonačno blizu realnom broju 3 . Odnosno, za svaki infinitezimal $\Delta x$ vrijedi da je

$$
\frac{\Delta f}{\Delta x}=3+3 \Delta x+(\Delta x)^{2}=3 \text {. }
$$

Dakle, funkcija $f$ je derivabilna u točki $x_{0}=1$ i vrijedi da je $f^{\prime}(1)=3$.

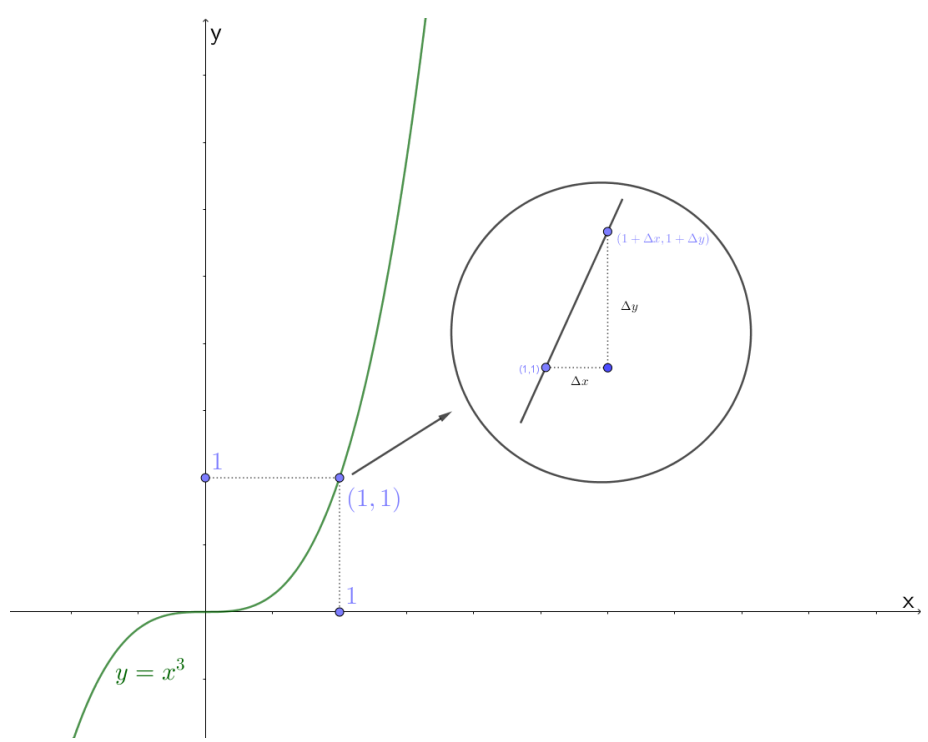

Slika 7

Sva pravila za deriviranje funkcija (zbroj, razliku, produkt, kvocijent, kompoziciju,...) mogu se izvesti i pomoću računa s infinitezimalima, a ovdje ćemo, zbog ilustracije, izvesti samo jedno od njih. Pravilo za derivaciju produkta funkcija pripisuje se upravo Leibnizu.

Teorem 11. Neka je $I \subseteq \mathbb{R}$ te $c \in I$. Pretpostavimo da su $f, g: I \rightarrow \mathbb{R}$ funkcije derivabilne $u$ točki $c$ i neka je $h=f g$. Tada je funkcija $h$ derivabilna u točki c i vrijedi

$$
h^{\prime}(c)=f^{\prime}(c) g(c)+f(c) g^{\prime}(c) .
$$


Dokaz. Za dani infinitezimal $\Delta x$ neka je $\Delta f=f(c+\Delta x)-f(c), \Delta g=$ $g(c+\Delta x)-g(c)$ i $\Delta h=h(c+\Delta x)-h(c)$. Slijedi da je

$$
\begin{aligned}
\frac{\Delta h}{\Delta x} & =\frac{h(c+\Delta x)-h(c)}{\Delta x}=\frac{f(c+\Delta x) g(c+\Delta x)-f(c) g(c)}{\Delta x} \\
& =\frac{(f(c)+\Delta f)(g(c)+\Delta g)-f(c) g(c)}{\Delta x} \\
& =\frac{f(c) \Delta g+\Delta f g(c)+\Delta f \Delta g}{\Delta x}=f(c) \frac{\Delta g}{\Delta x}+\frac{\Delta f}{\Delta x} g(c)+\Delta f \frac{\Delta g}{\Delta x} .
\end{aligned}
$$

Stoga je funkcija $h$ derivabilna te je dalje

$$
\begin{aligned}
h^{\prime}(c) & =\frac{\Delta h}{\Delta x}=f(c) \frac{\Delta g}{\Delta x}+\frac{\Delta f}{\Delta x} \frac{g(c)}{\Delta}+\frac{\Delta f}{\Delta x} \\
& =f(c) g^{\prime}(c)+f^{\prime}(c) g(c) .
\end{aligned}
$$

U narednim primjerima dajemo još neke primjere neprekidnih i derivabilnih funkcija, kao i onih koje to nisu, argumentirano infinitezimalnom metodom. I u nastavku promatramo realne funkcije realne varijable koje imaju svoja prirodna proširenja na skupu hiperrealnih brojeva.

Primjer 9. Dokažimo da je funkcija definirana s $f(x)=|x|$ neprekidna u 0 te da nije derivabilna u 0 .

Neka je $\Delta x \approx 0, \mathrm{tj} . \Delta x$ je infinitezimal. Također je $\mathrm{i}-\Delta x \approx 0$. Tada su $f(\Delta x)$ i $f(-\Delta x)$ infinitezimali te je funkcija neprekidna u 0.

Nadalje, za proizvoljan infinitezimal $\Delta x$ vrijedi:

$$
\frac{\Delta f}{\Delta x}=\frac{|0+\Delta x|-0}{\Delta x}= \begin{cases}1, & \Delta x>0 \\ -1, & \Delta x<0 .\end{cases}
$$

Uočavamo da vrijednost $\frac{\Delta f}{\Delta x}$ nije jednaka za sve infinitezimale $\Delta x$. Drugim riječima, prema definiciji ne postoji derivacija funkcije $f$ u 0 .

Darbouxov teorem tvrdi da funkcija derivacije $f^{\prime}$ dane (derivabilne) funkcije $f$ poprima sve međuvrijednosti na danom intervalu domene od $f$. Pritom $f^{\prime}$ ne mora biti na tom intervalu neprekidna (a onda ni derivabilna).

Primjer 10. Promotrimo funkciju definiranu s $f(x)=|x| x$.

$$
\begin{aligned}
& \text { Za } x>0 \text { je } f(x)=x^{2} \text { pa je } f^{\prime}(x)=\frac{(x+\Delta x)^{2}-x^{2}}{\Delta x}=2 x . \\
& \text { Za } x<0 \text { je } f(x)=-x^{2} \text { pa je } f^{\prime}(x)=\frac{(-x+\Delta x)^{2}-x^{2}}{\Delta x}=-2 x .
\end{aligned}
$$


Vrijedi: $\frac{\Delta f}{\Delta x}=\frac{(0+\Delta x)^{2}-0}{\Delta x}=0$

te je funkcija $f$ derivabilna u 0 i $f^{\prime}(0)=0$. Uočavamo i da je $f^{\prime}$ neprekidna u 0 , međutim, $f^{\prime}$ nije derivabilna u 0 . Za nju, naime, standardni dio kvocijenta diferencija nema istu vrijednost za svaki infinitezimal:

$$
\frac{\Delta f^{\prime}}{\Delta x}=\frac{2|0+\Delta x|-0}{\Delta x}= \begin{cases}2, & \Delta x>0 \\ -2, & \Delta x<0 .\end{cases}
$$

Primjer 11. Dokazat ćemo da je funkcija definirana s

$$
f(x)= \begin{cases}x^{2}, & x \in \mathbb{Q} \\ -x^{2}, & x \in \mathbb{R} \backslash \mathbb{Q}\end{cases}
$$

neprekidna i derivabilna samo u $x=0$, dok u svim drugim točkama ima prekid.

Najprije dokazujemo neprekidnost u 0 . Neka je $\delta \approx 0$, tj. infinitezimal. Kako je $\delta^{2} \approx 0$, kao i $-\delta^{2} \approx 0$, vrijedi da je $f(\delta) \approx 0$ pa je $f$ neprekidna $\mathrm{u} 0$.

Sada dokazujemo da $f$ ima prekid u svim ostalim točkama. Neka je $r \in \mathbb{R}, r \neq 0$. Pretpostavit ćemo da je pritom $r \in \mathbb{R} \backslash \mathbb{Q}$. Definiramo relaciju jezika $\mathcal{L}: \operatorname{Rac}(x):=$,x je racionalan.” Promotrimo rečenicu u $\mathcal{L}$ koja glasi:

$$
\forall a \forall b(a<b \rightarrow \exists c(a<c<b \wedge \operatorname{Rac}(c))) .
$$

Ova je rečenica istinita u $\mathbb{R}$ pa onda i u $\mathbb{R}^{*}$. Stoga za hiperrealan broj $\alpha \approx r$ postoji racionalan $q$ takav da je $\alpha<q<r$. Pretpostavimo li neprekidnost funkcije $\mathrm{u} r$, vrijedit će:

$$
\begin{gathered}
q \approx r \rightarrow q^{2} \approx r^{2}, \quad \text { ali vrijedi i } \\
q \approx r \rightarrow f(q)=q^{2} \approx-r^{2}=f(r), \quad \text { zbog definicije od } f .
\end{gathered}
$$

Kako je $-r^{2} \approx r^{2}$ zadovoljeno samo za $r=0$, u svim točkama $r \neq 0$ funkcija ima prekid. Tvrdnja se dokazuje analogno i za $r \in \mathbb{Q}$.

Dokazujemo još derivabilnost funkcije $f$ u nuli. Za dani infinitezimal $\delta$ vrijedi:

$$
\frac{f(0+\delta)-f(0)}{\delta}=\left\{\begin{array}{l}
\frac{\delta^{2}-0}{\delta}=\delta \\
\frac{-\delta^{2}-0}{\delta}=-\delta
\end{array}\right.
$$

pa je

$$
\frac{f(0+\delta)-f(0)}{\delta}=0,
$$

za sve $\delta$, tj. $f$ je derivabilna u 0 i $f^{\prime}(0)=0$. 


\section{Zaključak}

Opisani Robinsonov formalno logički pristup matematičkoj analizi uspješno je zaobišao pitanje na kojemu su se lomila koplja u prošlosti, o tome postoje li infinitezimali u objektivnom smislu. Robinson je, naime, zaista uspio opravdati Leibnizovu tvrdnju da je dovoljno da se može pravilno rasuđivati kao i da infinitezimali postoje. Ono što je bitno matematičarima današnjice jest izvjesnost da dokazi koji koriste infinitezimale u sebi ne sadrže proturječnosti. Nestandardna analiza je danas nadrasla početnu primjenu u diferencijalnom i integralnom računu. Prisutna je u modernoj apstraktnoj analizi, a koristi se kod radova o nestandardnoj dinamici, nestandardnoj vjerojatnosti... Jedan od pravaca u nestandardnoj analizi u širem smislu je i Nelsonova teorija unutarnjih skupova, svojevrsna nadogradnja klasične teorije skupova. Već je i Robinson koristio njene principe pri rješavanju dotad neriješenog problema o kompaktnim operatorima.

Dakle, danas nije pitanje - smiju li se infinitezimali koristiti, već - ima li smisla koristiti ih ako raspolažemo drugim sredstvima moderne analize? Standardna „ $\varepsilon, \delta$ " metoda, koliko god s vremenom postala intuitivna iskusnom matematičaru, toliko je uvijek nanovo vrlo apstraktna i prestrukturirana svakome onome tko se prvi put susreće s matematičkom analizom. Infinitezimali, s druge strane, studentima početnicima pružaju mogućnost intuitivnije predodžbe osnovnih pojmova matematičke analize te je kasnija nadogradnja standardnim pristupom prirodnija i lakša. Ovaj motivirajući pedagoški aspekt je prvi kojeg treba istaknuti u korist daljnje upotrebe nanovo "oživljenih" infinitezimala.

$\mathrm{S}$ druge strane, ako $\mathrm{u}$ istraživačkom radu želimo dokazati teorem o odnosima među standardnim objektima, njihovim smještanjem u nestandardno prošireno okruženje povećavamo vjerojatnost iznalaženja kraćeg i pronicljivijeg dokaza, upravo služeći se proširenim nestandardnim ambijentom.

Intuitivnost u sebi sadrži izvjesnu slobodu koja može rezultirati snažnim i bitnim probojima u znanosti. Upotreba infinitezimala u začecima matematičke analize je to već jednom pokazala. Možda bi infinitezimalima i u suvremenim istraživanjima, unatoč trenutno prisutnoj skeptičnosti nekih analitičara, trebalo i nadalje pružati šansu. Naposljetku, čak je i Arhimed, koji je svoje dokaze teorema provodio već opisanom metodom ekshaustije, dolazio do samih ingenioznih ideja upravo infinitezimalnim postupkom! Prema [2] o tome, naime, postoji i pisani trag. J. L. R. d'Alembert (1717. - 1783.), još jedan genijalni matematički um, zaključio je, pobijajući u njegovo vrijeme sumnjivu infinitezimalnu metodu: „Teorija limesa istinska je metafizika diferencijalnog računa". Vrlo je vjerojatno da bi mu Robinson na to odgovorio kako je to upravo 
- matematička logika. I dijalektička igra se nastavlja. . .

\section{Literatura}

[1] P. J. Davis, R. Hersh, E. A. Marchisotto, Doživljaj matematike, Tehnička knjiga, Zagreb, 2004.

[2] J. M. Henle, E. M. Kleinberg, Infinitesimal Calculus, Dover Books on Mathematics, 2003.

[3] H. J. Keisler, Elementary Calculus: An Infinitesimal Approach, Dover Books on Mathematics, 2012.

[4] A. Robinson, Non-standard Analysis, Princeton University Press, 1996.

[5] M. Vuković, Matematička logika, Element, Zagreb, 2009.

Neda Lovričević

Fakultet građevinarstva, arhitekture i geodezije, Sveučilište u Splitu, Split

E-mail adresa: neda.lovricevic@gmail.com

Anita Rezić

Fakultet prirodoslovno-matematičkih i odgojnih znanosti, Sveučilište u Mostaru, Mostar, Bosna i Hercegovina

E-mail adresa: anita.rezic92@gmail.com 